\title{
СПІВРОБІТНИЦТВО МІЖ УКРАЇНОЮ ТА ЄС У СФЕРІ ВИКОРИСТАННЯ НАДР У КОНТЕКСТІ СТАЛОГО РОЗВИТКУ МІНЕРАЛЬНО-СИРОВИННОГО КОМПЛЕКСУ
}

\author{
Сурілова О. О., Зубайр Ахмад
}

\section{ВСТУП}

Надра відіграють суттєву роль в економіці України, забезпечують вагому частку національного продукту, є однією зі складових частин екологічних систем. Однак останнім часом зазнають значної шкоди в результаті їх виснажливого нераціонального використання, що негативно впливає на мінерально-сировинну безпеку України, якість навколишнього природного середовища та умови життя населення. Це зумовлює завдання досягнення економічного зростання за рахунок власного мінеральносировинного потенціалу за умови сталого розвитку самого вітчизняного мінерально-сировинного комплексу. Це означає гарантоване забезпечення поточних і майбутніх потреб економіки держави в мінеральній сировині в необхідній кількості та належної якості за будь-яких змін внутрішніх і зовнішніх факторів процесу надрокористування у разі одночасного збереження навколишнього природного середовища ${ }^{1}$. Слід також ураховувати те, що ресурси надр не обмежуються корисними копалинами. Умови для економічного зростання створює також раціональне використання просторових та рекреаційних ресурсів надр.

Необхідною умовою вирішення цього завдання $\epsilon$ розробка та запровадження ефективної моделі публічного адміністрування в цій сфері, що потребує переосмислення низки положень щодо порядку надання надр у користування задля досягнення якісно нового рівня економічного та соціального розвитку та гарантування державної безпеки нашої держави, іii життєво важливих національних інтересів. Надрокористування має перейти на європейські принципи та стандарти публічного адміністрування в контексті взятих Україною зобов'язань відповідно Угоди про асоціацію між Україною та Свропейським Союзом.

\section{1. Стратегії та ініціативи СС щодо співробітництва з Україною у сфері використання надр}

Головна спрямованість сучасних процесів у мінерально-сировинному комплексі $\mathrm{CC} \mathrm{-} \mathrm{це} \mathrm{створення} \mathrm{стратегії} \mathrm{CC} \mathrm{у} \mathrm{цій} \mathrm{галузі,} \mathrm{основним}$

\footnotetext{
${ }^{1}$ Матюха В.В., Сухіна О.М. Мінерально-сировинний комплекс України у контексті сталого розвитку економіки. Економіка України. 2017. № 1. С. 64-79.
} 
концептуальним принципом якої є стале забезпечення СС мінеральною сировиною.

Сталий розвиток гірничовидобувного комплексу передбачає екологічно безпечне надрокористування та впровадження заходів попередження аварій на видобувних об'єктах. У повідомленні Комісії «Безпечна діяльність добувних підприємств: звіт 3 остатніх нещасних випадків на шахті» проаналізовано випадок забруднення Дунаю, спричинене розливом ціаніду в Бая Маре (Румунія) внаслідок руйнування хвостосховища та забруднення довкілля національного парку Доньяна, спричиненого аварією на гірничовидобувному підприємстві в Асналькольярі (Іспанія) $)^{2}$. У повідомленні констатується, що нині в СС $є$ низка правових інструментів, які стосуються екологічних аспектів гірничої діяльності (Директиви 2011/92/СС Свропейського Парламенту та Ради про оцінку впливу окремих державних і приватних проектів на навколишнє середовище (кодифікація); 2010/75/СС Про промислове забруднення; 2012/18/ЕС Про контроль великих аварій, пов'язаних 3 небезпечними речовинами), однак розуміння ризиків, властивих гірничодобувній галузі, є незадовільним, рівень комунікації між різними ланками влади, недержавними організаціями та громадськістю, готовність до надзвичайних ситуацій, реагування на аварії та запобігання шкоди є низькими. Тому особливої актуальності набуло питання підвищення ефективності політики СС, спрямованої на запобігання подібних катастроф.

У повідомленні констатовано, що з точки зору цивільного захисту досвід цих техногенних аварій чітко демонструє необхідність поліпшення систем раннього попередження. Тому Комісія запропонувала створити механізм координації заходів цивільного захисту у разі надзвичайної ситуації та визнала необхідність запровадити юридичну відповідальність 3 метою покращення реалізації ключових екологічних принципів, таких як забруднювач платить, запобігання, а також розробити запобіжні заходи, як зазначено у Білій книзі СС з екологічної відповідальності ${ }^{3}$. Передбачені й інші заходи щодо управління промисловими ризиками, відходами гірничої промисловості та інтегрованого запобігання та контролю забруднення.

Зазначимо, що в сфері управління промисловими ризиками та запобігання масштабних аварій найбільш дієвим законодавчим інструментом є Директива 2012/18/EC (Seveso III), яка зобов'язує операторів промислових об'єктів запровадити систему управління, включаючи детальну оцінку ризику на

\footnotetext{
${ }^{2}$ COM(2000) 664 final COMMUNICATION FROM THE COMMISSION Safe operation of mining activities: a follow-up to recent mining accidents / COMMISSION OF THE EUROPEAN COMMUNITIES. URL: https://eur-lex.europa.eu/LexUriServ (дата звернення: 15.02.2019).

${ }^{3}$ White Paper on Environmental Liability. COM (2000) 66 final, 9 February 2000 (follow-up to the Green Paper). European Commission. URL: http://ec.europa.eu/environment/legal/liability/pdf/el_full.pdf (дата звернення: 18.02.2019).
} 
основі можливих сценаріїв аварії відповідно до принципу запобігання та попередження, зокрема розробити внутрішні і зовнішні плани дій в аварійних ситуаціях, а також встановити процедури, що забезпечують необхідні випробування, перевірку та виконання таких планів у разі виникнення великої аварії або ймовірності ії виникнення ${ }^{4}$. На суб'єкта господарювання також покладений обов'язок надавати компетентним органам влади досить інформації, аби останні могли визначити потенційні загрози та їхнє джерело. Суб'єкт господарювання також складає i, якщо цього вимагає національне законодавство, направляе до відповідного компетентного органу план щодо запобігання великим аваріям (МАРР), який передбачає загальний підхід і заходи (включаючи належні системи управління безпекою), спрямовані на боротьбу із загрозами виникнення великих аварій. Під час виявлення та оцінки суб'єктом загроз великих аварій необхідно також ураховувати небезпечні речовини, що можуть утворюватися під час серйозної аварії на підприємстві.

У директиві звернено увагу на необхідність запровадження заходів безпеки, спрямованих на зменшення ризику та запобігання можливих транскордонних наслідків аварій з метою забезпечення високого рівня захисту на території всього Союзу. Зазначимо також, що транскордонні наслідки можуть зачіпати і країни-сусіди, тому ці положення стосуються і України.

У квітні 2014 року відповідно до Програми із запобігання, готовності та реагування на катастрофи природного та техногенного характеру для країн Східного партнерства в м. Брашові (Румунія) відбувся четвертий заключний семінар 3 контролю ризиків виникнення великих аварій 3 викидом небезпечних речовин у рамках Директиви CC SEVESO. Україна як країна-партнер брала участь у семінарі та доклала чимало зусиль для вивчення Директиви та визначення заходів щодо гармонізації власного законодавства до вимог ЄС у цій сфері.

Директива SEVESO III спрямована на запобігання великих аварій, пов'язаних $з$ небезпечними речовинами, а також обмеження їх впливу на здоров'я людини i довкілля 3 метою послідовного та ефективного забезпечення високого рівня захисту у всьому Союзі. В контексті нашого дослідження важливо зазначити, що ця Директива, як це вказано у ст. 2 , не застосовується до розробки, розвідки родовищ, видобутку та переробки корисних копалин, розвідки і розробки шельфових родовищ корисних копалин, включаючи вуглеводні; зберігання газу у підземних морських сховищах, включаючи об'єкти, спеціально призначені для зберігання, та

\footnotetext{
4 Directive 2012/18/EU (Seveso-III-Directive). European Parliament and of the Council. URL: https://eur-lex.europa.eu/legalontent/en (дата звернення: 15.02.2019).
} 
місця, де також здійснюються розвідка і розробка родовищ корисних копалин, зокрема, вуглеводнів; місць для розміщення відходів, включаючи підземні сховища для відходів.

Разом із цим відповідно до тієї ж ст. 2 зберігання газу в берегових підземних сховищах, операції з хімічної та термічної обробки, а також зберігання (у зв'язку з такими операціями), пов'язане з небезпечними речовинами, так само як і чинні об'єкти зі знешкодження хвостів збагачення, зокрема хвостосховища та хвостові дамби, що містять небезпечні речовини, мають бути включені до сфери цієї Директиви.

Директивою передбачений механізм публічного адміністрування запобігання аварій. По-перше, держави-члени створюють або призначають компетентний орган, відповідальний за виконання обов'язків, встановлених цією Директивою, і у разі необхідності - органи, які зобов'язані надавати допомогу компетентному органу на технічному рівні та забезпечують повне координування процедур виконання ними своїх обов'язків.

По-друге, визначені адміністративно-правові засоби мінімізації шкоди ідентифікація компетентним органом усіх небезпечних підприємств або їх груп, де ризик або наслідки великої аварії можуть збільшуватися через географічне положення та розташування таких підприємств на близькій відстані, а також їхніх переліків небезпечних речовин; планування землекористування; оцінка ризиків виникнення великих аварій; вироблення плану дій на випадок аварій; контроль ситуації на небезпечних об'єктах; координація дій компетентних органів влади; залучення зацікавленої громадськості; управління інформацією.

3 метою забезпечення мінерально-сировинної безпеки розроблений Стратегічний план ETP SMR, що зосереджується на забезпеченні промисловості власними мінеральними ресурсами, удосконаленні законодавчої бази та порядку надання дозволів на користування надрами: розробці механізмів забезпечення екологічної безпеки під час здійснення видобувної діяльності 5 .

Директоратом промисловості Сврокомісії було анонсовано мінеральносировинну ініціативу, головною ідеєю якої є підтримка СС та країнамичленами розробки мінерально-сировинної політики на основі вільного та прозорого ринку з використанням міжнародних багатосторонніх договорів за участю $\mathrm{CC}$ та третіх країн. Ініціатива констатує, що доступність мінеральної сировини є визначальною для функціонування економіки $Є C$,

\footnotetext{
${ }^{5}$ European Platform on Sustainable Mineral Resources (ETP SMR). URL: https://www.google.com/search? (дата звернення: 15.02.2019).
} 
а забезпечення надійного та неупередженого доступу до корисних копалин стає все більш важливим фактором конкурентоспроможності ЄС.

Головними завданнями мінерально-сировинної політики $\epsilon C \quad \epsilon$ : 1) збільшення постійного постачання мінеральної сировини з європейських джерел; 2) забезпечення постійного й прозорого постачання сировини 3 третіх країн; 3) розбудова мінерально-сировинних комплексів у країнах, що розвиваються; 4) заохочення ефективного використання мінеральних ресурсів; 5) запровадження сучасної системи знань у сфері мінеральних ресурсів.

Головною умовою забезпечення мінерально-сировинної безпеки на континенті визначено включення умов доступу до мінеральних ресурсів $\mathrm{i}$ стале управління ними в усі двосторонні та багатосторонні торгові договори ${ }^{6}$. Таким чином, ініціатива заклала підвалини співробітництва Європейського Союзу з Україною в галузі реформування та сталого розвитку мінерально- сировинного комплексу.

Практичним кроком до виведення співробітництва на новий рівень $\epsilon$ прийняття України до складу Асоціації геологічних служб країн Європи (АГСЄ) на правах асоційованого члена. Україна також набула статусу партнера АГСЄ. Відповідно до положень Статуту АГСЄ прийнято рішення про призначення Українського державного геологорозвідувального інституту (УкрДГРІ) повноважним представником Державної геологічної служби України в АГСС 7 .

У 2015 р. Україна стала асоційованим членом Рамкової програми Європейського Союзу 3 досліджень та інновацій «Горизонт 2020» наймасштабнішої Рамкової програми Європейського Союзу 3 фінансування науки та інновацій із загальним бюджетом близько 80 мільярдів євро, яка розрахована на 2014-2020 роки. Програма спрямована на вирішення трьох головних завдань: 1) зробити Європу привабливим місцем для першокласних науковців; 2) сприяти розвитку інноваційності та конкурентоспроможності європейської промисловості й бізнесу; 3) на науковій основі вирішувати найбільш гострі проблеми сучасного європейського суспільства та має такі ключові пріоритети передова наука; лідерство у промисловості та суспільні виклики.

«Горизонт 2020» надає підтримку широкому спектру діяльності, від наукових досліджень до демонстраційних проектів та інновацій, готових до виходу на ринок.

\footnotetext{
${ }^{6}$ TAIEX workshop on Sustainable Mineral Resources. / The European Technology Platform on Sustainable Mineral Resources (ETP SMR) Ljubljana. Slovenia. December 10-11.2007. URL: http Www.geo-zS.si/TAIEXtaiex. html (дата звернення: 17.02.2019).

${ }^{7}$ Гошовський С.В. Малюк Б.І. Мінерально-сировинна стратегія Свропейського Союзу. Стаття 3. Роль геологічних служб. Стратегічні пріоритети. 2009. № 3(12). С. 157-163.
} 
3 липня 2015 року Україна $\epsilon$ асоційованим членом програми, що створює нові можливості для співробітництва у сфері науки і технологій та закладає основу для структурних реформ у науково-інноваційній сфері України. Для фінансування за програмою «Горизонт 2020» уже прийнято 90 проектів, до яких залучені українські науковці, на них уже надійшло понад 17 млн 230 тис. євро.

Європейським Союзом було визначено сім пріоритетних напрямів, в яких інвестиції в дослідження та інновації можуть принести реальну користь громадянам, серед яких - зміна клімату, довкілля, ресурсоефективність і корисні копалини. У рамках цього розділу здійснюється фінансування досліджень та інновацій за такими напрямами: забезпечення ефективності використання ресурсів і стійкості суспільства та економіки до зміни клімату; охорона природних ресурсів та екологічних систем, а також раціональне управління ними; збалансоване постачання та використання сировини для забезпечення потреб світового населення ${ }^{8}$.

Україна як держава, яка декларує власний європейський вибір, безперечно, зобов'язана формувати свою політику розвитку мінеральносировинного комплексу в загальноєвропейському контексті. Позитивним кроком у цьому напрямі $\epsilon$ прийняття Загальнодержавної програми розвитку мінерально-сировинної бази України на період до 2030 р.9.

Правові основи співробітництва в цій сфері визначені в Угоді про асоціацію між Україною та $\epsilon^{10}$. Результатом їх запровадження має бути створення системи надійного та екологічно безпечного постачання мінеральної сировини в обсягах, необхідних для розвитку як економіки ЄС, так і України.

Ст. 339 Угоди ставить задачу підтримки процесу регуляторних реформ, який включає реструктуризацію вугільного сектору (енергетичного, коксованого та бурого вугілля) 3 метою підвищення його конкурентоспроможності, безпеки шахт і гірників, а також послаблення негативного впливу на навколишнє середовище, при цьому враховуючи регіональний та соціальний вплив. 3 метою підвищення ефективності, конкурентоспроможності та стабільності процес реструктуризації має охоплювати всі етапи вугільного і всього гірничого виробництва.

\footnotetext{
8 Горизонт 2020. Рамкова програма ЄС 3 досліджень та інновацій. /Урядовий офіс 3 питань європейської інтеграції. / Секретаріат Кабінету Міністрів України. URL: https://www.kmu.gov.ua/storage/app/media/uploaded (дата звернення: 20.02.2019).

9 Про затвердження Загальнодержавної програми розвитку мінерально-сировинної бази України на період до 2030 року : Закон України від 21 квітня 2011 року № 3268-VI. / Верховна Рада України. Відомості Верховної Ради Украӥни. 2011. № 44. Ст. 457.

10 Угода про асоціацію між Україною, з однієї сторони, та Європейським Союзом, Свропейським співтовариством 3 атомної енергії і їхніми державами-членами, з іншої сторони. Документ 984 _011/ Верховна Рада України. URL: https://zakon.rada.gov.ua/laws/show/984_011 (дата звернення: 20.02.2019).
} 
Водночас стаття 361 Угоди проголошує, що співробітництво, зокрема у гірничовидобувній галузі, має на меті збереження, захист, поліпшення і відтворення якості навколишнього середовища, захист громадського здоров'я, розсудливе та раціональне використання природних ресурсів та заохочення заходів на міжнародному рівні, спрямованих на вирішення регіональних і глобальних проблем навколишнього середовища у сферах: зміна клімату; екологічне управління та доступ до інформації з питань навколишнього середовища та процесу прийняття рішень; якість атмосферного повітря; якість води та управління водними ресурсами; управління відходами та ресурсами; охорона природи, зокрема збереження $\mathrm{i}$ захист біологічного та ландшафтного різноманіття (екомережі); промислове забруднення і промислові загрози; шумове забруднення.

Конкретні заходи щодо реалізації цих завдань мають включати: спрощення та забезпечення сталості доступу до власних мінеральних ресурсів; сприяння проведенню геологорозвідувальних робіт; збільшення обсягів наукових досліджень та впровадження інноваційних технологій у районах видобутку корисних копалин; запровадження нових підходів до вирішення питань охорони здоров'я та безпеки у видобувній промисловості; удосконалення законодавчої бази та системи надання дозволів на користування надрами; розробку систем раціонального поєднання видобутку мінеральних ресурсів та охорони довкілля.

Вирішення цих завдань передбачає створення відповідного законодавства, яке дало б змогу мінімізувати імпорт гостродефіцитної сировини: кольорових, рідкісних, рідкісноземельних, дорогоцінних металів, збільшити видобуток власних нафти і газу, значно підвищити економічну незалежність і безпеку держави, забезпечити екологічну безпеку держави.

3 метою забезпечення мінерально-сировинної безпеки для досягнення цілей Мінерально-сировинної ініціативи СС 1 грудня 2017 р. було започатковано проект «Мінеральні ресурси у галузі сталого планування землекористування〉 (MINLAND), що фінансується Європейською Комісією за програмою досліджень та інновацій Horizon 2020. Проект MINLAND виходить 3 необхідності збереження важливих мінеральних ресурсів (включаючи критичні) для нинішнього і майбутніх поколінь, запорукою чого стане інтеграція політики мінеральних ресурсів до планування землекористування на різних рівнях, від місцевого до загальноєвропейського, що одночасно $є$ ключовим фактором для досягнення цілей Мінерально-сировинної ініціативи СС (МCI), однією 3 основ якої є доступ до мінеральних ресурсів у Європі. 
Проект виконує консорціум геологічних служб Швеції, Чехії, України, Франції та інших європейських країн, а також професійних асоціацій СС (EuroGeoSurveys, Euromines, European Aggregates Association, Industrial Minerals Association Europe). Україну в проекті представляє ДНВП «Геоінформ України» ${ }^{11}$. Участь ДНВП «Геоінформ України» у проекті MINLAND здійснюється на засадах Угоди про співробітництво третіх сторін з Асоціацією геологічних служб Європи (АГСЄ) ${ }^{12}$. Партнери мають значну компетентність і досвід у галузі управління земельними та мінеральними ресурсами, що закладає міцну основу для співробітництва та дає змогу успішно планувати видобувні роботи та здійснювати землевпорядкування ${ }^{13}$.

Проект MINLAND спрямований на дослідження можливостей включення мінерально-сировинних ресурсів до процесу планування землекористування. Проектом передбачено: виявлення основних проблем i перспектив, пов'язаних з плануванням землекористування і видобутку мінеральних ресурсів і того, як це може бути пов'язане з національною мінерально-сировинною політикою; порівняння наслідків видобувної діяльності 3 екосистемними послугами; аналіз конфлікту із землекористуванням; розвідку мінеральних ресурсів у районах проживання корінних народів. Тематичні дослідження мають ураховувати різні інтереси, точки зору і масштаби.

Проектом запропоновано можливі галузі для вивчення: невідомі ресурси i планування землекористування; регіональне/місцеве комплексне планування землекористування; міське планування (регіональне майбутнє сценарне моделювання); аналіз конфліктів використання земель (тематичні дослідження, включаючи моделювання); життєвий цикл копальні/кар'єру (проект планування життєвого циклу; перехідний вплив); інтеграція даних 3D кадастру щодо наземного та підземного простору.

Для взаємозв'язку регіонального і місцевого розвитку та експлуатації критичних видів сировини намічено використання платформи LUISA ${ }^{14}$, яка дає змогу оцінити варіанти і сценарії освоєння мінеральних ресурсів на національному рівні 3 урахуванням важливих аспектів у галузі землекористування, таких як демографія, соціально-економічні тенденції,

11 ДНВП «Геоінформ України» - науково-виробнича установа Державної служби геології та надр України, яка збирає, зберігає, аналізує та надає у користування інформацію, що утворилася в процесі геологічного вивчення та використання надр.

12 Рішення НTP Держгеонадр від 16.12.2013 р., протокол № 73. / Держгеонадра України. URL: www.geo.gov.ua (дата звернення: 20.02.2019).

13 ДНВП «ГЕОІНФОРМ УКРАЇНИ» / Державна служба геології та надр України. URL: http://geoinf.kiev.ua/mizhnarodne-spivrobitnytstvo-1 (дата звернення: 20.02.2019).

14 LUISA / EU Science Hub - European Commission URL: https://ec.europa.eu (дата звернення: 17.02.2019). 
географічне положення, а також необхідну інфраструктуру (наприклад, транспортну, енергетичну). Очікувані результати сприятимуть освоєнню родовищ корисних копалин, що мають суспільне значення в національній мінерально-сировинній політиці з урахуванням європейських підходів. Ці підходи мають бути враховані в удосконаленні правового порядку надання надр у користування в Україні.

\section{2. Порядок надання надр у користування в Україні: проблемні питання}

В основі правового порядку надання надр у користування лежить дозвільна система, яка, як слушно відзначає М. Дудар, $є$ правовою формою такої функції екологічного управління, як розподіл та перерозподіл природних ресурсів, полягає у наданні надр виключно на правовому титулі користування. В майбутньому виникнення, зміна і припинення відносин надрокористування має реалізовуватись у рамках не дозвільної, а договірної системи, вважає фахівець ${ }^{15}$, однак ми не можемо погодитися 3 цією позицією.

Велике значення надр для життя суспільства зумовлює те, що держава у цій сфері не мусить обмежуватися роллю спостерігача навіть за обмеження адміністративно-командних засад економіки i розвиткові ринкових відносин. Порядок надання надр у користування має забезпечувати активну роль держави у визначенні напрямів розвитку гірничої галузі та використання надр 3 іншою метою $з$ урахуванням пріоритетів державної соціально-економічної та екологічної політики. Надання надр у користування переслідує також мету контролю використання ресурсів надр за дотримання норм екологічної безпеки. Разом із цим надання дозволів не має перетворюватися на адміністративну перешкоду, ланку у корупційних схемах, такий собі бізнес від влади.

Надання надр у користування $\epsilon$ адміністративною процедурою, адже йому властиві всі ознаки адміністративних процедур, які визначаються $\mathrm{H}$. Губерською як нормативно встановлений порядок послідовно здійснюваних дій органів публічної адміністрації, спрямованих на прийняття владних управлінських рішень і реалізацію повноважень, не пов'язаних із розглядом спорів або застосуванням заходів примусу ${ }^{16}$. Стадіями цієї процедури $є$ надання спеціального дозволу на здійснення надрокористування, надання гірничого відводу, надання земельної

15 Дудар М. Дозвільна система у сфері використання та охорони надр як форма розподілу і перерозподілу природних ресурсів: правові аспекти. Підприємництво, господарство і право. 2017. № 1 . C. $107-112$.

${ }^{16}$ Губерська Н.Л Зміст і значення адміністративних процедур у сфері вищої освіти. Науковий вісник Херсонського державного університету. Серія «Юридичні науки». № 5. 2014. С. 94-99. 
ділянки, необхідної для здійснення надрокористування. Для того щоб усунути термінологічну плутанину, визначимо адміністративну процедуру надання надр у користування та іiі стадії як адміністративну процедуру та стадії в широкому розумінні, на відміну від традиційного розуміння змісту цих дефініцій. У випадках, передбачених законодавством, додатковою підставою визнається укладення договору.

Як витікає 3 п. 1 ст. 24 Кодексу України про надра головною передумовою здійснення надрокористувачами своїх прав $є$ наявність у них спеціального дозволу. Ст. 16 Кодексу України про надра визначає порядок надання спеціальних дозволів на здійснення діяльності щодо користування надрами. Головною метою встановлення такого порядку є контроль за законністю i раціональністю користування надрами та лімітування використання надр.

Право власності на надра і ресурси надр належить народу України. Коли уповноважені державні органи надають їх у користування, вони здійснюють розпорядження цими ресурсами від імені народу України. Ресурси надр надаються в користування на умовах, які встановлює держава 3 метою раціонального їх використання, 3 одного боку, i забезпечення екологічної безпеки -3 іншого. Надрокористувач зобов'язаний виконувати умови, на яких отримав надра у користування i які встановлені державою.

Тут виявляється юридичний зміст адміністративного права, йому властивий імперативний метод регулювання суспільних відносин. Надання спеціального дозволу на право користування ресурсами надр являє собою владно-розпорядчу діяльність органів державної влади, а сам дозвіл $\epsilon$ управлінським рішенням.

Порядок діяльності дозвільних органів, уповноважених видавати документи дозвільного характеру, та державних адміністраторів врегульований Законом України «Про дозвільну систему у сфері господарської діяльності» ${ }^{17}$. Надання спеціальних дозволів на користування надрами передбачене Порядком надання спеціальних дозволів на користування надрами ${ }^{18}$. Дія цього Порядку поширюється на всі види користування надрами у межах території України, піi континентального шельфу та виключної (морської) економічної зони.

Основним завданням надання спеціальних дозволів на використання надр $\epsilon$ пошук оптимальних рішень. Але на практиці найчастіше рішення

\footnotetext{
${ }^{17}$ Про дозвільну систему у сфері господарської діяльності : Закон України від 06.09.2005 № 2806-IV / Верховна Рада України. URL: http://zakon4.rada.gov.ua/l (дата звернення: 20.02.2019).

${ }^{18}$ Порядок надання спеціальних дозволів на користування надрами, затв. Постановою КМ України від 30.05.2011 № 615 / Кабінет Міністрів України. URL: http://zakon3.rada.gov.ua/ (дата звернення: 20.02.2019).
} 
приймаються за принципом вимушеної раціональності, а не оптимальності. Визначальним критерієм ефективності управлінських рішень слід вважати якість вирішення управлінських ситуацій. Щодо прийняття рішення про надання спеціальних дозволів на користування надрами якісне рішення означає досягнення економічного результату у разі забезпечення екологічної безпеки.

Право на користування надрами засвідчується актом про надання гірничого відводу, який надається на підставі спеціального дозволу на використання надр. Ділянки надр, що надаються у користування, обмежуються у підземному просторі та координатами на поверхні. Положення є спірним. Справа в тому, що визначити межі ділянки надр у просторі можна лише під час надання гірничого відводу на підставі топографічного плану підземного простору. Конкретною ділянка стає саме в результаті визначення гірничого відводу. Необхідно усунути цю суперечність.

Для розробки родовищ корисних копалин та використання надр для інших цілей необхідно мати певну площу земної поверхні, яка використовується для потреб, пов'язаних із користуванням надрами. Відповідно до ст. 66 Земельного кодексу України надання земельних ділянок для потреб, пов'язаних із користуванням надрами, проводиться після оформлення в установленому порядку прав користування надрами i відновлення земель згідно із затвердженим проектом рекультивації на раніше відпрацьованих площах у встановлені строки ${ }^{19}$.

Порядок надання земель для потреб, пов'язаних із користуванням надрами, визначається метою надрокористування, залежить від виду корисних копалин (загальнодержавного або місцевого значення), від засобу видобутку (відкритого чи підземного). Підставою для використання земельних ділянок для проведення геологорозвідувальних робіт $є$ договір між землевласником і геологорозвідувальним підприємством, юридична природа якого не встановлена досі.

Не має сумніву в тому, що проведення на земельній ділянці геологорозвідувальних робіт суттєво обмежує можливості використання іiі за призначенням власником або користувачем. 3 іншого боку, суспільні інтереси заслуговують уваги. 3 метою їх забезпечення вбачається необхідним усунути перешкоди на шляху розвитку гірничої промисловості, забезпечити можливість пошуків і розвідки родовищ корисних копалин. Саме земельна власність може виявитися основним утрудненням на шляху розвитку гірничодобувної галузі. Насамперед

\footnotetext{
19 Земельний кодекс України : Закон України від 25.10.2001 № 2768-III / Верховна Рада України. URL: http://zakon2.rada.gov.ua/(дата звернення: 17.02.2019).
} 
необхідно вирішити питання про те, чи зобов'язаний власник землі або землекористувач укладати угоду на проведення геологорозвідувальних робіт. Чинне цивільне законодавство декларує принцип волі договору. Постає питання: Чи можна обмежувати права землевласників, захист яких гарантується Конституцією та законодавством України?

Задача законодавця полягає саме у досягненні приємного компромісу не тільки між інтересами гірничої промисловості і землевласників (землекористувачів), але також між економічними й екологічними інтересами суспільства.

Вважаємо, що цю проблему необхідно вирішувати виходячи перш за все 3 форми власності на земельну ділянку i виду корисних копалин (державного або місцевого значення). Якщо земельна ділянка перебуває у державній власності, цілком можливо передбачити обов'язок землекористувача щодо укладення угоди про проведення на земельній ділянці геологорозвідувальних робіт. Це положення слід передбачити тільки щодо розвідки корисних копалин загальнодержавного значення. Щодо інших видів надрокористування і видобутку корисних копалин місцевого значення, то інтереси землевласників i землекористувачів необхідно визнати рівноцінними.

Щодо суб’єктів, яким належать земельні ділянки на праві приватної або комунальної власності, то здійснення геологорозвідувальних робіт на земельній ділянці суттєво обмежує їхні права. Тому на проведення геологорозвідувальних робіт необхідна їхня згода. У цьому разі можливе укладення договору про оренду земельної ділянки відповідно до Закону України «Про оренду землі» ${ }^{20}$. Потреби розвідки родовищ корисних копалин загальнодержавного значення доцільно розглядати як державну i громадську потребу, враховуючи значення мінерально-сировинної бази для держави і суспільства. Тому необхідно розробити порядок і умови вилучення (викупу) земель у разі, коли землевласник або землекористувач не дає згоди на здійснення геологорозвідувальних робіт та укладання договору оренди земельної ділянки.

Відповідно до ст. 22 Закону України «Про режим іноземного інвестування» $^{21}$ розробка природних ресурсів може здійснюватися на підставі концесійних договорів. Звертає на себе увагу основна риса концесійних правовідносин - вони виникають на підставі владного публічно-правового акта концедента, який опосередковується концесійним договором, що дає змогу стверджувати, що концесії мають

\footnotetext{
20 Про оренду землі : Закон України від 06.10.1998 № 161-XIV / Верховна Рада України. URL: http://zakon2.rada.gov.ua/ (дата звернення: 20.02.2019).

21 Про режим іноземного інвестування : Закон України від 19.03.1996 № 93/96-ВР / Верховна Рада України. URL: http://zakon2.rada.gov.ua/ (дата звернення: 20.02.2019).
} 
адміністративно-правову природу, а концесійний договір $\epsilon$ адміністративно-правовим договором.

Відповідно до ст. 3 КАС України адміністративний договір - дво- або багатостороння угода, зміст якої становлять права та обов'язки сторін, що випливають із владних управлінських функцій суб'єкта владних повноважень, який є однією зі сторін угоди ${ }^{22}$.

На відміну від адміністративного акта, приписам якого мають підпорядковуватися всі, кому він адресований, незалежно від їхньої волі, стати учасником договірних відносин 3 органами державної влади можна виключно на добровільній основі ${ }^{23}$. В. Колпаков слушно зауважує, що, підкоряючись волі видавця нормативного акта, сторони вступають у рівноправні договірні відносини між собою, а суттєві обмеження волі контрагентів в адміністративному порядку (неможливість відмовитись від укладення договору, наявність відповідальності за відмову від укладення договору та ін.) спонукані до позначення таких договорів терміном «адміністративний договір». Суб'єкти, визначені таким актом, укладають договір стосовно: а) вибору засобів, необхідних для ефективного вирішення поставленого завдання; б) розробки механізму спільного використання цих засобів; в) визначення ролі та місця кожної зі сторін у цьому механізмі; г) прийняття на себе зобов'язань діяти у встановлених межах i за узгодженою схемою; г) встановлення відповідальності за невиконання прийнятих зобов'язань ${ }^{24}$.

Обов'язковими ознаками адміністративного договору є такі: однією зі сторін завжди $є$ суб'єкт владних повноважень; за своїм змістом адміністративний договір - це угода, а не адміністративний акт; зміст такої угоди нерозривно пов'язаний з владно-управлінськими функціями суб'єкта владних повноважень. Фактично реалізація суб'єктом владних повноважень та саме адміністративної, а не цивільної правосуб'єктності є невід'ємною ознакою адміністративного договору.

Закон України «Про концесії» регулює концесійні відносини у контексті Директиви ЄС про концесії ${ }^{25}$ та визначає концесію як надання 3 метою задоволення громадських потреб уповноваженим органом

\footnotetext{
${ }^{22}$ Кодекс адміністративного судочинства : Закон України_від 06.07.2005 № 2747-IV / Верховна Рада України. URL: http://zakon2.rada.gov.ua/ (дата звернення: 20.02.2019).

${ }^{23}$ Бортник Н.П. Адміністративний договір як форма публічного управління в сфері організації послуг 3 перевезення пасажирів автомобільним транспортом. Вісник Національного університету «Львівська політехніка». Юридичні науки. 2014. № 810. С. 11-16.

24 Колпаков В.К. Адміністративно-правові відносини: поняття і види. Юридичний науковий електронний журнал. 2013. № 1. С. 101-104. URL: http://www.lsej.org.ua/1_2013/ukr/ (дата звернення: 20.02.2019).

${ }^{25}$ Про концесії : Закон України від 16.07.1999 № 997-XIV / Верховна Рада України. URL: http://zakon1.rada.gov.ua/(дата звернення: 20.02.2019).
} 
виконавчої влади чи органом місцевого самоврядування на підставі концесійного договору на платній та строковій основі юридичній або фізичній особі (суб'єкту підприємницької діяльності) права на створення (будівництво) та (або) управління (експлуатацію) об'єкта концесії (строкове платне володіння) за умови взяття суб'єктом підприємницької діяльності (концесіонером) на себе зобов'язань зі створення (будівництва) та (або) управління (експлуатацію) об'єктом концесії, майнової відповідальності та можливого підприємницького ризику. На нашу думку, гірнича концесія - це надання юридичній або фізичній особі (суб'єкту підприємницької діяльності) на підставі концесійного договору права на використання або здійснення управління об’єктом гірничої концесії (юридично відокремленою ділянкою надр - гірничим відводом) з метою пошуку, розвідки та видобування корисних копалин. Результатом надання об'єкту концесії є виникнення гірничих концесійних відносин. Суттєвою відзнакою концесії є те, що суб'єктом підприємницької діяльності роботи виконуються за свій рахунок і на свій ризик.

Дискусійним питанням $\epsilon$ правова природа договору про розподіл продукції, відповідно до якого одна сторона - держава доручає іншій стороні - інвестору на визначений строк проведення пошуку, розвідки та видобування корисних копалин на визначеній ділянці (ділянках) надр та ведення пов'язаних з угодою робіт, а інвестор зобов'язується виконати доручені роботи за свій рахунок і на свій ризик з наступною компенсацією витрат і отриманням плати (винагороди) у вигляді частини прибуткової продукції ${ }^{26}$. На нашу думку, угоди про розподіл продукції, як і концесійні договори, являють собою адміністративні договори. В Україні в світлі асоціації України до Свропейського Союзу розширяється сфера застосування адміністративних договорів у сфері використання надр, адже вони надають можливість досягти балансу суспільних та особистих інтересів землевласників та землекористувачів, гармонізують застосування адміністративних та ринкових механізмів у сфері надрокористування та сприяють прогресу у ринковій інтеграції мінерально-сировинного сектору до ЄС.

Необхідною умовою запровадження європейських стандартів публічного адміністрування надрокористування в Україні $є$ гармонізація відповідного законодавства до вимог ЄС. Так, до нормативно- правових актів $€ C$, впровадження яких $є$ обов'язковим для України відповідно Угоди про асоціацію, відносять Директиву 2012/18/ЄС Європейського

\footnotetext{
26 Про угоди про розподіл продукції :_Закон України від 14.09.1999 № 1039-XIV / Верховна Рада України. URL: http://zakon2.rada.gov.ua/(дата звернення: 20.02.2019).
} 
Парламенту та Ради від 4 липня 2012 р. Про контроль значних аварій, пов'язаних з небезпечними речовинами. Аналіз положень законодавства України свідчить про те, що воно частково відповідає вимогам Директиви 2012/18/ЄС, однак необхідне внесення змін до Закону України «Про об'єкти підвищеної небезпеки», розроблення нової редакції Правил техногенної безпеки.

3 урахуванням цього Державною службою України з надзвичайних ситуацій розроблений проект Закону України «Про внесення змін до деяких законодавчих актів України щодо об'єктів підвищеної небезпеки» ${ }^{27}$, яким передбачено доповнити Закон статтею $2^{1}$, в якій визначено сферу дії цього Закону. До неї підпадають об'єкти розвідки, видобутку та розробки корисних копалин, включаючи розвідку та розробку морського дна, якщо небезпечні речовини на таких об'єктах не підняті на поверхню і перебувають у звичайному природному середовищі, зокрема вуглеводні; підземні шельфові об’єкти природного газу.

\section{ВИСНОВКИ}

Україна має значний потенціал для сталого розвитку гірничовидобувної галузі. Мінерально-сировинна база країни включає значні ресурси корисних копалин, які використовуються в різних секторах економіки. В Україні розроблена стратегія розвитку мінерально- сировинного комплексу, запроваджуються реформи 3 метою вдосконалення системи публічного адміністрування в сфері надрокористування та виконання зобов'язань, які наша країна взяла на себе відповідно до Угоди про асоціацію між ЄС та Україною.

Україна бере участь у багатьох європейських проектах, спрямованих на розвиток гірничовидобувної галузі, мінімізацію завданої навколишньому середовищу шкоди, виявлення потенційних ризиків та попередження аварій за допомогою законодавчих інструментів, серед яких слід виділити Директиву Seveso III, яка має на меті забезпечення високого рівня захисту людей та довкілля шляхом запобігання великих аварій, пов'язаних 3 небезпечними речовинами.

Проблемним питанням $\epsilon$ поширення іiі дії на геологорозвідувальну та видобувну діяльність, адже положення Директиви виводять їх зі сфери дії Директиви, що знижує ефективність діяльності Союзу в сфері контролю техногенної безпеки. Проблема частково вирішується включенням у сферу

\footnotetext{
${ }^{27}$ Проект Закону України «Про внесення змін до деяких законодавчих актів України щодо об'єктів підвищеної небезпеки» / Державна служба України 3 надзвичайних ситуацій. URL: http://www.dsns.gov.ua/ua/ (дата звернення: 20.02.2019).
} 
дії директиви об’єктів зі знешкодження хвостів збагачення, хвостосховищ, операцій з небезпечними речовинами.

Серед інших проектів СС у сфері забезпечення мінерально-сировинної безпеки - Мінерально-сировинна ініціатива, спрямована на забезпечення стабільного постачання мінерально-сировинних ресурсів, посилення співробітництва $Є С$ та третіх країн 3 використанням міжнародних багатосторонніх договорів. На виконання цієї ініціативи Україна як асоційований член була прийнята до складу Асоціації геологічних служб країн Свропи, є асоційованим членом Рамкової програми Європейського Союзу з досліджень та інновацій «Горизонт 2020», бере участь у проекті MINLAND, дослідницькій платформі LUISA.

Реформа надрокористування в Україні передбачає вдосконалення порядку надання надр у користування. Однак з огляду на те, що надра є об'єктом власності народу України, який здійснює це право через державні органи влади, навіть у разі переходу на ринкові відносини в сфері використання надр держава зберігає повноваження щодо розпорядження надрами, зокрема надання їх у користування. При цьому поширюється практика укладання адміністративних договорів - договору концесії, договору про розподіл продукції. Непересічне значення в процесі реформування має гармонізація надрового законодавства України до вимог ЄС.

\section{АНОТАЦІЯ}

Україна має потужну мінерально-сировинну базу, яка здатна забезпечити потреби економіки України у довгостроковій перспективі. Стаття присвячена дослідженню правових основ публічного адміністрування в сфері сталого постачання мінерально-сировинних ресурсів в Європейському Союзі та Україні, проблемним питанням реформування надрокористування в Україні 3 урахуванням положень Угоди про асоціацію Україна - СС та визначенню правових основ співробітництва України та ЄС у видобувній галузі.

Встановлено, що в Свропейському Союзі запроваджено низку ініціатив, платформ програм, спрямованих на забезпечення країн-членів СС мінеральними ресурсами в достатній кількості та попередження техногенних аварій на гірничовидобувних об'єктах. Розроблена Стратегічна платформа ETP SMR, в якій передбачені механізми забезпечення промисловості власними мінеральними ресурсами, зокрема удосконалення законодавчої бази та порядку надання дозволів на користування надрами: розробка механізмів забезпечення екологічної безпеки у разі здійснення видобувної діяльності. 
У сфері запобігання аварій найбільш дієвим законодавчим інструментом $\epsilon$ Директива 2012/18/EC (Seveso III), яка, незважаючи на обмеження іii застосування у гірничовидобувній діяльності, грає визначну роль у сфері управління ризиками, пов'язаними з відходами цієї діяльності, зокрема експлуатації хвостосховищ.

Основи співробітництва України та СС у мінерально-сировинній сфері закладені в Угоді про асоціацію між Україною та ЄС та мінеральносировинній ініціативі $€$, яка акцентує увагу на необхідності посилення співробітництва $Є С \quad 3$ третіми країнами у видобувній галузі 3 використанням міжнародних багатосторонніх договорів.

Україна розглядається як надійний партнер $Є C$ у мінеральносировинній галузі, про що свідчить надання нашій державі статусу асоційованого члена Асоціації геологічних служб країн Європи та Рамкової програми Європейського Союзу 3 фінансування науки та інновацій «Горизонт 2020».

Запровадження європейських стандартів публічного адміністрування надрокористування в Україні пов'язане 3 гармонізацію відповідного законодавства до вимог СС, зокрема внесення змін до Закону України «Про об’єкти підвищеної небезпеки», розроблення нової редакції Правил техногенної безпеки.

\section{ЛITЕРАТУРА}

1. COM(2000) 664 final COMMUNICATION FROM THE COMMISSION Safe operation of mining activities: a follow-up to recent mining accidents. COMMISSION OF THE EUROPEAN COMMUNITIES. URL: https://eurlex.europa.eu/LexUriServ (дата звернення: 15.02.2019).

2. Directive 2012/18/EU (Seveso-III-Directive). European Parliament and of the Council. URL:https://eur-lex.europa.eu/legalontent/en (дата звернення: 15.02.2019).

3. European Platform on Sustainable Mineral Resources (ETP SMR) URL: https://www.google.com/search? (дата звернення: 15.02.2019).

4. LUISA / EU Science Hub - European Commission. URL: https://ec.europa.eu (дата звернення: 17.02.2019).

5. TAIEX workshop on Sustainable Mineral Resources. The European Technology Platform on Sustainable Mineral Resources (ETP SMR). Ljubljana. Slovenia. December 10-11.2007. URL: http Www.geo-zS.si/TAIEXtaiex.html (дата звернення: 17.02.2019).

6. White Paper on Environmental Liability. COM (2000) 66 final, 9 February 2000 (follow-up to the Green Paper). European Commission. URL: 
http://ec.europa.eu/environment/legal/liability/pdf/el_full.pdf (дата звернення: 18.02.2019).

7. Бортник Н.П. Адміністративний договір як форма публічного управління в сфері організації послуг 3 перевезення пасажирів автомобільним транспортом. Вісник Національного університету «Львівська політехніка». Юридичні науки. 2014. № 810. С. 11-16.

8. «Горизонт 2020». Рамкова програма ЄС з досліджень та інновацій. / Урядовий офіс 3 питань європейської інтеграції. Секретаріат Кабінету Міністрів України. URL: https://www.kmu.gov.ua/storage/app/media/uploaded (дата звернення: 20.02.2019).

9. Гошовський С.В., Малюк Б.І. Мінерально-сировинна стратегія Європейського Союзу. Стаття 3. Роль геологічних служб. Стратегічні nріоритети. 2009. № 3(12). С. 157-163.

10. Губерська Н.Л Зміст і значення адміністративних процедур у сфері вищої освіти. Науковий вісник Херсонського державного університету. Серія «Юридичні науки». № 5. 2014. С. 94-99.

11. ДНВП «ГЕОІНФОРМ УКРАЇНИ» / Держгеонадра України. URL: http://geoinf.kiev.ua/mizhnarodne-spivrobitnytstvo (дата звернення: 20.02.2019).

12. Дудар М. Дозвільна система у сфері використання та охорони надр як форма розподілу і перерозподілу природних ресурсів: правові аспекти. Підприємництво, господарство і право. 2017. № 1. С. 107-112.

13. Земельний кодекс України : Закон України від 25.10.2001 № 2768-III. / Верховна Рада України. URL: http://zakon2.rada.gov.ua/(дата звернення: 17.02.2019).

14. Кодекс адміністративного судочинства : Закон України від 06.07.2005 № 2747-IV / Верховна Рада України. URL: http://zakon2.rada.gov.ua/(дата звернення: 20.02.2019).

15. Колпаков В.К. Адміністративно-правові відносини: поняття і види. Юридичний науковий електронний журнал. 2013. № 1. URL: http://www.lsej.org.ua/1_2013/ukr/ C.101-104 (дата звернення: 20.02.2019).

16. Матюха В.В., Сухіна О.М. Мінерально-сировинний комплекс України у контексті сталого розвитку економіки. Економіка Украӥни. 2017. № 1. С. 64-79.

17. Порядок надання спеціальних дозволів на користування надрами, затв. Постановою КМ України від 30.05.2011 № 615 / Кабінет Міністрів України. URL: http://zakon3.rada.gov.ua (дата звернення: 20.02.2019).

18. Про дозвільну систему у сфері господарської діяльності : Закон України від 06.09.2005 № 2806-IV / Верховна Рада України. URL: http://zakon4.rada.gov.ua/1 (дата звернення: 20.02.2019). 
19. Про затвердження Загальнодержавної програми розвитку мінерально-сировинної бази України на період до 2030 року : Закон України від 21 квітня 2011 року № 3268-VI. / Верховна Рада України. Відомості Верховної Ради України. 2011. № 44. Ст. 457.

20. Про концесії : Закон України від 16.07.1999 № 997-XIV / Верховна Рада України. URL: http://zakon1.rada.gov.ua/ (дата звернення: 20.02.2019).

21. Про оренду землі : Закон України від 06.10.1998 № 161-XIV / Верховна Рада України. URL: http://zakon2.rada.gov.ua/ (дата звернення: 20.02.2019).

22. Про режим іноземного інвестування : Закон України від 19.03.1996 № 93/96-ВР / Верховна Рада України. URL: http://zakon2.rada.gov.ua/ (дата звернення: 20.02.2019).

23. Про угоди про розподіл продукції : Закон України від 14.09.1999 № 1039-XIV / Верховна Рада України. URL: http://zakon2.rada.gov.ua/ (дата звернення: 20.02.2019).

24. Рішення НТР Держгеонадр від 16.12.2013 р., протокол № 73. / Держгеонадра України. URL: www.geo.gov.ua (дата звернення: 20.02.2019).

25. Угода про асоціацію між Україною, 3 однієї сторони, та Європейським Союзом, Свропейським співтовариством з атомної енергії і їхніми державами-членами, з іншої сторони / Верховна Рада України. URL: https://zakon.rada.gov.ua/laws/show/984_011 (дата звернення: 20.02.2019).

26. Проект Закону України «Про внесення змін до деяких законодавчих актів України щодо об'єктів підвищеної небезпеки» / Державна служба України 3 надзвичайних ситуацій. URL: http://www.dsns.gov.ua/ua/ (дата звернення: 20.02.2019).

\section{Information about authors: Surilova O. O., Doctor of Law, Professor.} Associate Professor Department of International and European Law National University "Odessa Law Academy" 23, Fontanska doroga, Odessa, Ukraine

Zubair Akhmad, Postgraduate at the Department of International and European Law National University "Odessa Law Academy" 23, Fontanska doroga, Odessa, Ukraine 